ex Instituto Archaeologico Universitatis de Rolando Eötvös nominatae

C

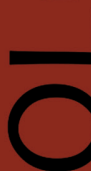

ப

$\varangle$

工

$\cup$

ه

$<$

in

ㄴ
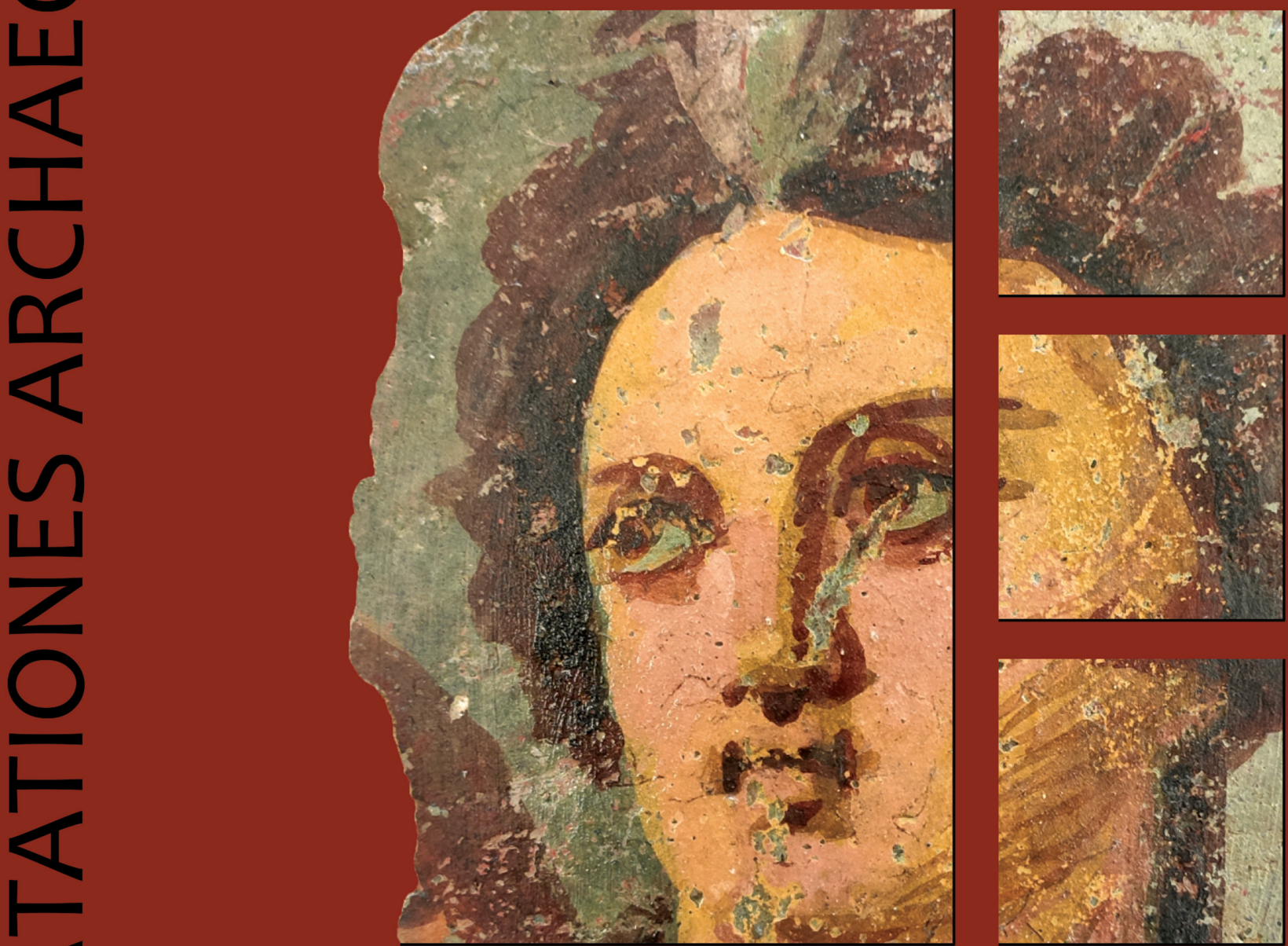

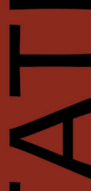

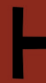

ח

Ш

un

n

0
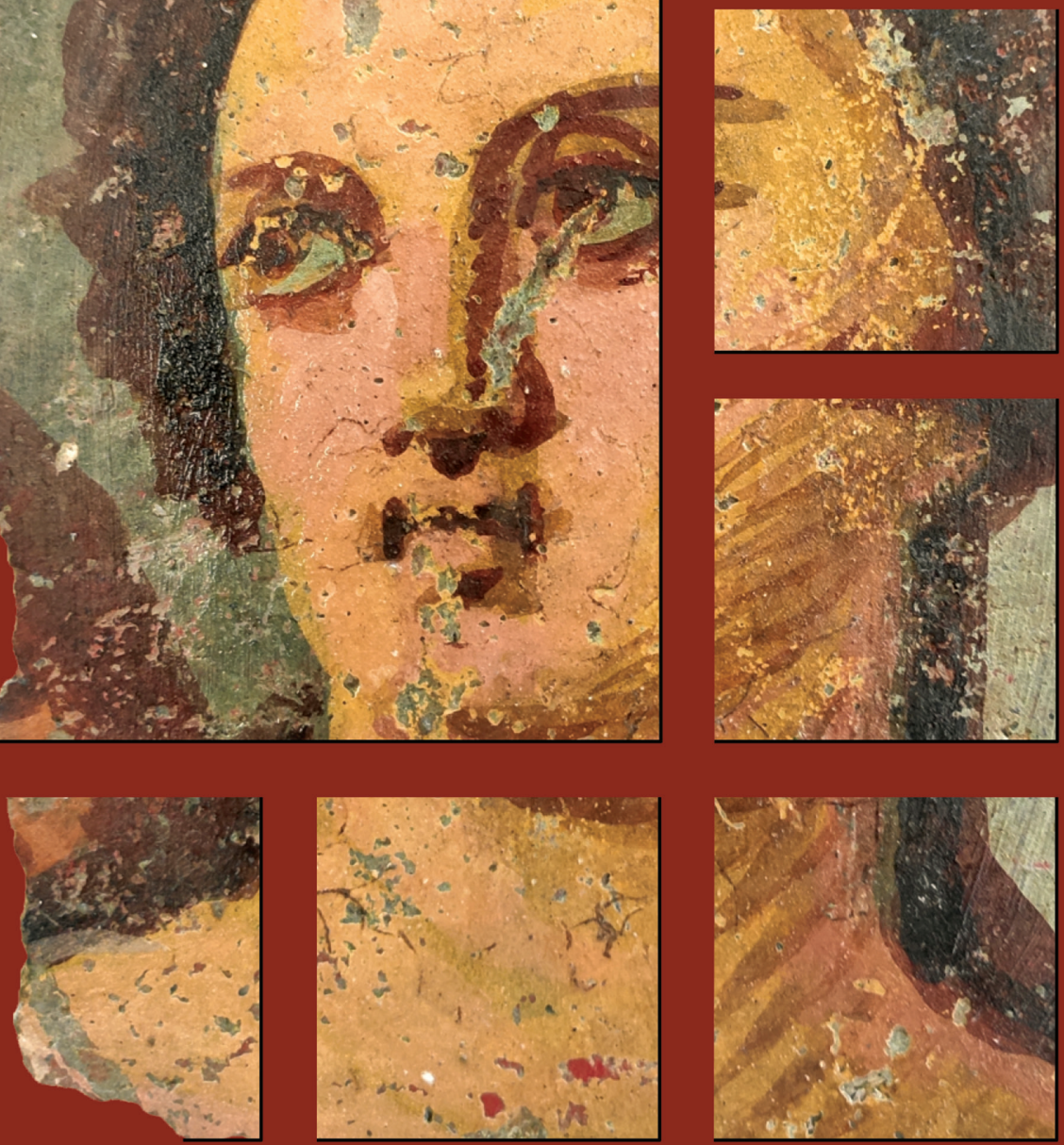

Serp 30 No. 8. 2020 


\section{Dissertationes Archaeologicae ex Instituto Archaeologico}

Universitatis de Rolando Eötvös nominatae Ser. 3. No. 8.

Budapest 2020 
Dissertationes Archaeologicae ex Instituto Archaeologico Universitatis de Rolando Eötvös nominatae Ser. 3. No. 8.

Editor-in-chief:

DÁvid Bartus

Editorial board:

LÁsZló BARTOSIEWICZ

LÁsZLÓ BORHY

ZOLTÁN CZAJLIK

IsTVÁN FELD

GÁBOR KALLA

PÁL RACZKY

MiKLÓS SZABÓ

Tivadar Vida

Technical editor:

Gábor VÁczi

Proofreading:

Szilvia BARTUS-SzÖLLŐsI

Zsófia KondÉ

Márton SZILÁGYI

Aviable online at http://ojs.elte.hu/dissarch

Contact: dissarch@btk.elte.hu

ISSN 2064-4574

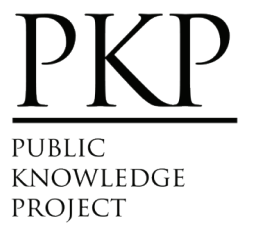

๑ ELTE Eötvös Loránd University, Institute of Archaeological Sciences

Layout and cover design: Gábor Váczi

Budapest 2020 


\section{CONTENTS}

\section{ARTICLES}

Maciej WAWRZCZAK - Zuzana KASENČÁKovÁ

Stará L'ubovña - Lesopark. Late Palaeolithic site and the problems associated with raw material mining

Attila PÉNTEK - Norbert FARAgó

Chipped stone assemblages from Schleswig-Holstein (North Germany) in the collection of the Institute of Archaeological Sciences - ELTE Eötvös Loránd University

Bence Soós 49

Middle Iron Age Cemetery from Alsónyék, Hungary

Tamás Szeniczey - Tamás Hajdu 107

Appendix - Results of the analysis of the Early Iron Age human remains unearthed at Alsónyék, Hungary

Lajos JuHÁsz - József Géza Kiss

Bound in bronze - a Roman bronze statuette of a barbarian prisoner

Csilla SÁRó

The fibula production of Brigetio: clay moulds

\section{Field Reports}

András Füzesi - Knut Rassmann - Eszter BÁnffy - Hajo Hoehler-Brockmann -

Gábor Kalla - Nóra Szabó - Márton SzIlágyi - Pál Raczky

Test excavation of the "pseudo-ditch" system of the Late Neolithic settlement complex at Öcsöd-Kováshalom on the Great Hungarian Plain

Gábor VÁczi - László RupNIK - Zoltán CZAJLIK - Gábor MEsterházy Bettina BitTner - Kristóf FÜlöP - Denisa M. LÖNHARdT - Nóra Szabó

The results of a non-destructive site exploration and a rescue excavation at the site of Pusztaszabolcs-Dohányos völgy északi part

Dávid BArtus - László Borhy - Szilvia JohÁczi - Emese SzÁmadó 181

Excavations in the legionary fortress of Brigetio in 2019 
Dávid BArtus - László Borhy - Emese SzÁmadó - Lajos Juhász - Bence Simon -

Ferenc Barna - Anita Benes - Szilvia Joháczi - Rita Olasz - Melinda Szabó

Excavations in Brigetio in 2020

\section{Thesis Abstracts}

Anett OszTÁs

The settlement history of Alsónyék-Bátaszék.

Complex analysis of its buildings in the context of the Lengyel culture

Csilla SzÁRAz

The region of the Zala and Mura Rivers (Zala County) in the Late Bronze Age.

Late Tumulus and Urnfield period

Ágnes KIRÁly

Human remains unearthed in settlement context from the Late Bronze Age -

Early Iron Age (Reinecke BD-HaB3) Northeastern Hungary

Gergely BóKA

Transformation of settlement history in the Körös Region in the period between the Late Bronze Age and the end of Iron Age

Gabriella G. DeLbó

Pottery production of the settlement complex of Brigetio

Adrienn Katalin BLAY

Die Beziehungen zwischen dem Karpatenbecken und dem Mediterraneum

von der II. Hälfte des 6. bis zum 8. Jahrhundert n. Chr. anhand Schmuckstücken

und Kleidungszubehör

Levente SAMU

293

Die mediterranen Kontakte des Karpatenbeckens in der Früh- und Mittel-

awarenzeit im Licht der Männerkleidung. Gürtelschnallen und Gürtelgarnituren

\section{REviEWS}

Gábor MESTERHÁZY

Czajlik, Z. - Črešnar, M. - Doneus, M. - Fera, M. - Hellmith Kramberger, A. Mele, M. (eds): Researching Archaelogical Landscapes Across Borders - Strategies,

Methods and Decisions for the 21th Century. Graz-Budapest, 2019. 


\title{
The results of a non-destructive site exploration and a rescue excavation at the site of Pusztaszabolcs-Dohányos völgy északi part
}

\section{Gábor VÁczi}

Institute of Archaeological Sciences

ELTE Eötvös Loránd University

vaczi.gabor@btk.elte.hu

Zoltán CZAJLIK

Institute of Archaeological Sciences

ELTE Eötvös Loránd University

czajlik.zoltan@btk.elte.hu

Bettina BitTNER

Castle Headquaters

Integrated Developement Centre

bittnerbettina@gmail.com

Denisa M. LÖNHARDT

Institute of Archaeological Sciences

ELTE Eötvös Loránd University

lonhardt.denisa@gmail.com
László RuPNIK

MTA - ELTE Research Group for Interdisciplinary Archaeology

rupnik.laci@gmail.com

Gábor MEsTERHÁzY

Castle Headquaters Integrated Developement Centre gabor.mesterhazy@gmail.com

Kristóf FÜLÖP

Institute of Archaeological Sciences ELTE Eötvös Loránd University

fulopkr14@gmail.com

Nóra SzABó

Institute of Archaeological Sciences

ELTE Eötvös Loránd University

szabonori91@gmail.com

\begin{abstract}
It is only possible in rare cases to compare aerial photographs, fieldwork data, surveys of two types of magnetometer measurements, and metal detector surveys of a site with the results of a previous rescue excavation. The cooperation of the Castle Headquaters Integrated Developement Centre, the Szent István Király Museum of Székesfehérvár, and the Institute of Archaeological Sciences at the Eötvös Loránd University made the discovery of the multi-period site on the outskirts of Pusztaszabolcs possible.
\end{abstract}

\section{Introduction}

The archaeological site is located by the southern border of Pusztaszabolcs, on the left bank of the Dohányos Stream. ${ }^{1}$ Our site was previously registered as two sites: the area near the stream was known as Pusztaszabolcs-Kullancsos (93149), further away from the stream it was known as Pusztaszabolcs-Dohányos völgy (82537). In the Preliminary Archaeological Documentation, the Kullancsos site was merged with the larger Dohányos völgy site (Fig. 1).

1 Entrusted by the Szent István Király Museum - Székesfehérvár, the Institute of Archaeological Sciences of the Eötvös Loránd University (ELTE-IAS) carried out the excavation. Staff of the excavation: Gábor V. Szabó project leader; Gábor Váczi leader of the excavation; Dániel Borza, András Bödőcs, Kristóf Fülöp, Polett Kósa, Denisa M. Lönhardt, László Rupnik, Nóra Szabó archaeologists; Marcell Barcsi, Gizella Kovács, Péter Mogyorós, Lajos Sándor technicians. 


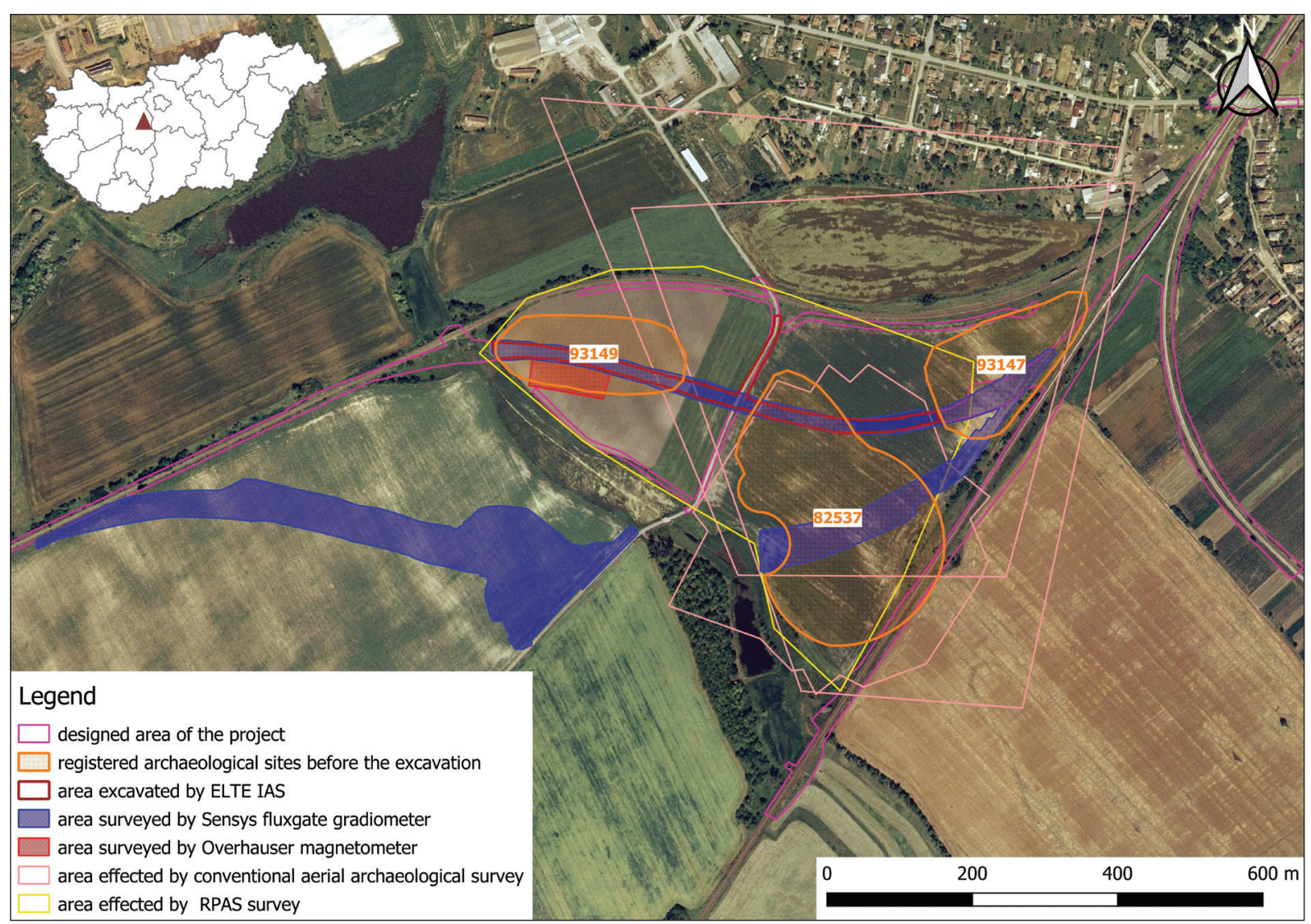

Fig. 1. The registered archaeological sites and their surroundings with the area of the planned railway line (map: L. Rupnik).

The construction of a new railway track made it necessary to rescue the affected parts of the site. The site covered a 600-meter section along a 20-25-meter wide west-east trail. This was complemented by the exploration of a 120-meter section of a 10-meter dirt road running north. In the east-west direction, we obtained a complete cross-section of the site from the heavily populated strip near the stream to the sparsely populated high hills. The western part of the trail near the stream and the eastern border is covered with grass, while the rest is an agricultural area.

Along the dirt route, the gradual removal of the humus layer was not possible, as the dirt road was regularly filled with construction debris, sometimes sinking to the subsoil in the wheel tracks. We were able to remove the humus in the railway track in two or three layers, which enabled the use of the metal detector. The loose soil of the high-lying areas was heavily eroded, and farming has moved the soil towards the stream. In the strip along the stream, the filling was 1-1.5 meter, and in many places the subsoil has exposed to the surface.

\section{Non-invasive archaeological research}

\section{Aerial archaeology}

The aerial archaeological research that has been carried out at the site can be divided into three major categories: evaluating the accessible archive imagery, processing the aerial photographs from the collection of the Institute of Archaeological Sciences at the Eötvös Loránd University, and last but not least the assessment of the images taken in parallel with the excavation. Among the archive imagery those were applied that had been available in digital 


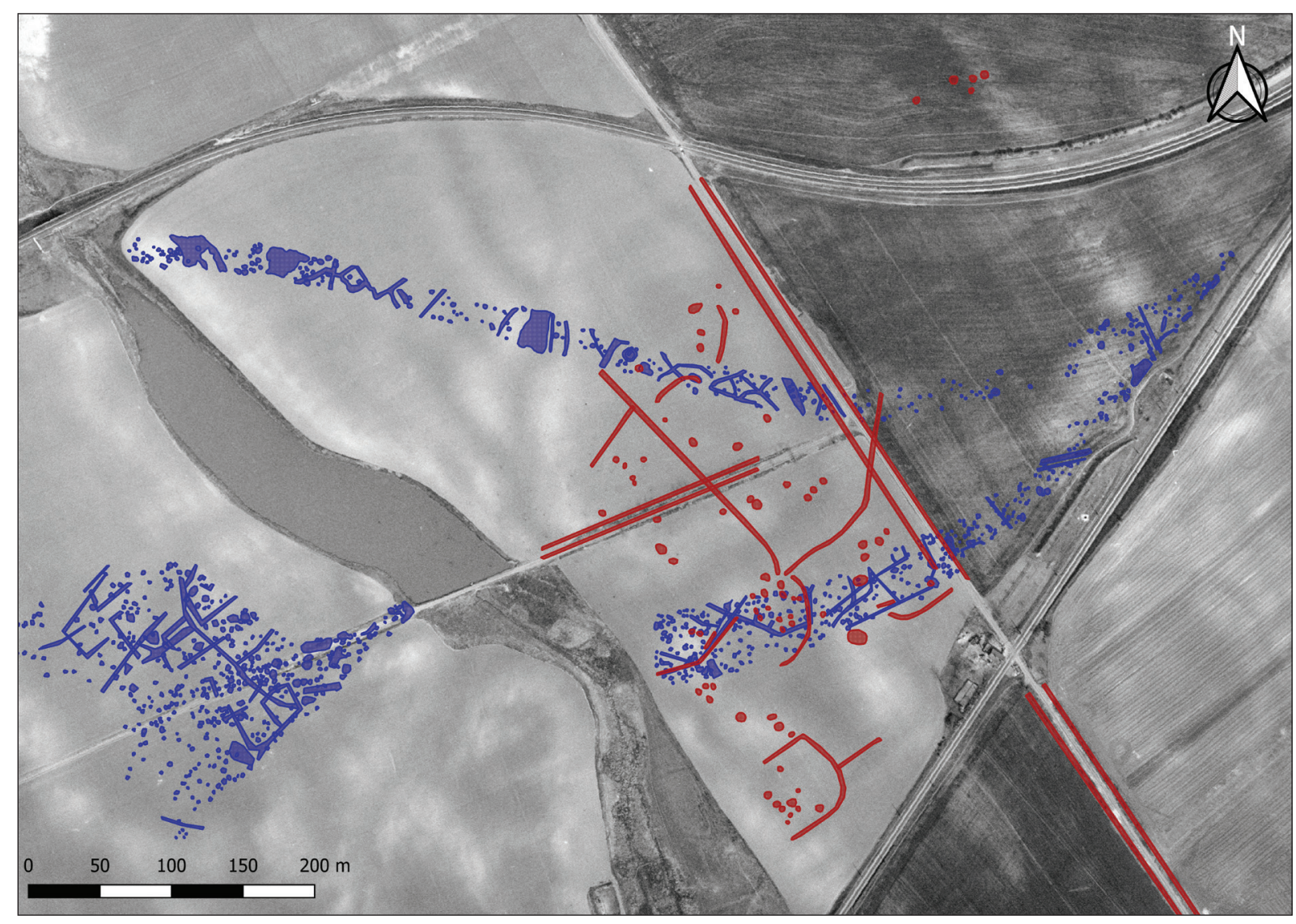

Fig. 2. The vertical aerial photograph from 1968 with the magnetic anomalies (blue) and the crop marks of aerial archaeological survey (red) (graphic: L. Rupnik).

form at the fentrol.hu website. These vertical photographs have proven helpful during the reconstruction of the earlier field system in the Dohányos völgy site. The main dirt road heading towards Felsőcikola following an approx. NW-SE direction can be observed in the image taken in $1968 .^{2}$ This road had already appeared on the sheet of the First Military Survey. Besides, another field road existed for a while that connected to this main road in right angle. Trenches followed both roads on their sides according to the testimony of the modern aerial photography, the magnetic prospection, and the excavation as well (Fig. 2).

The Dohányos völgy belongs among the areas in Hungary that were thoroughly examined by René Gougey and later Zoltán Czajlik using the methods of traditional aerial archaeology since the beginning of the end of the 1990's. The complete presentation of this research is beyond the limits of the current work, thus only information relevant to the site under review will be presented. The SE section of the site was photographed on the 15th June 2011 and 26th June 2015. During the aerial photography we used a Cessna 152 airplane, and the photos were taken with a Nikon D300 camera, using an AF Nikkor 24-70mm, 1:2,8G ED camera lens, from a height of about 300 meters. Although the circumstances were not favourable in either case, positive crop marks of pits, sunken-featured houses, and an extensive system of trenches could be detected, particularly in the southern part of the area. The inhomogeneous background of the images may be an indication that some of the archaeological features have been partially

2 1968_0015_9833. Last accessed: 09.03.2020. https://www.fentrol.hu/hu/legifoto/168174?r=1\&c=2086923. 6891549998:5962683.994111501:7 

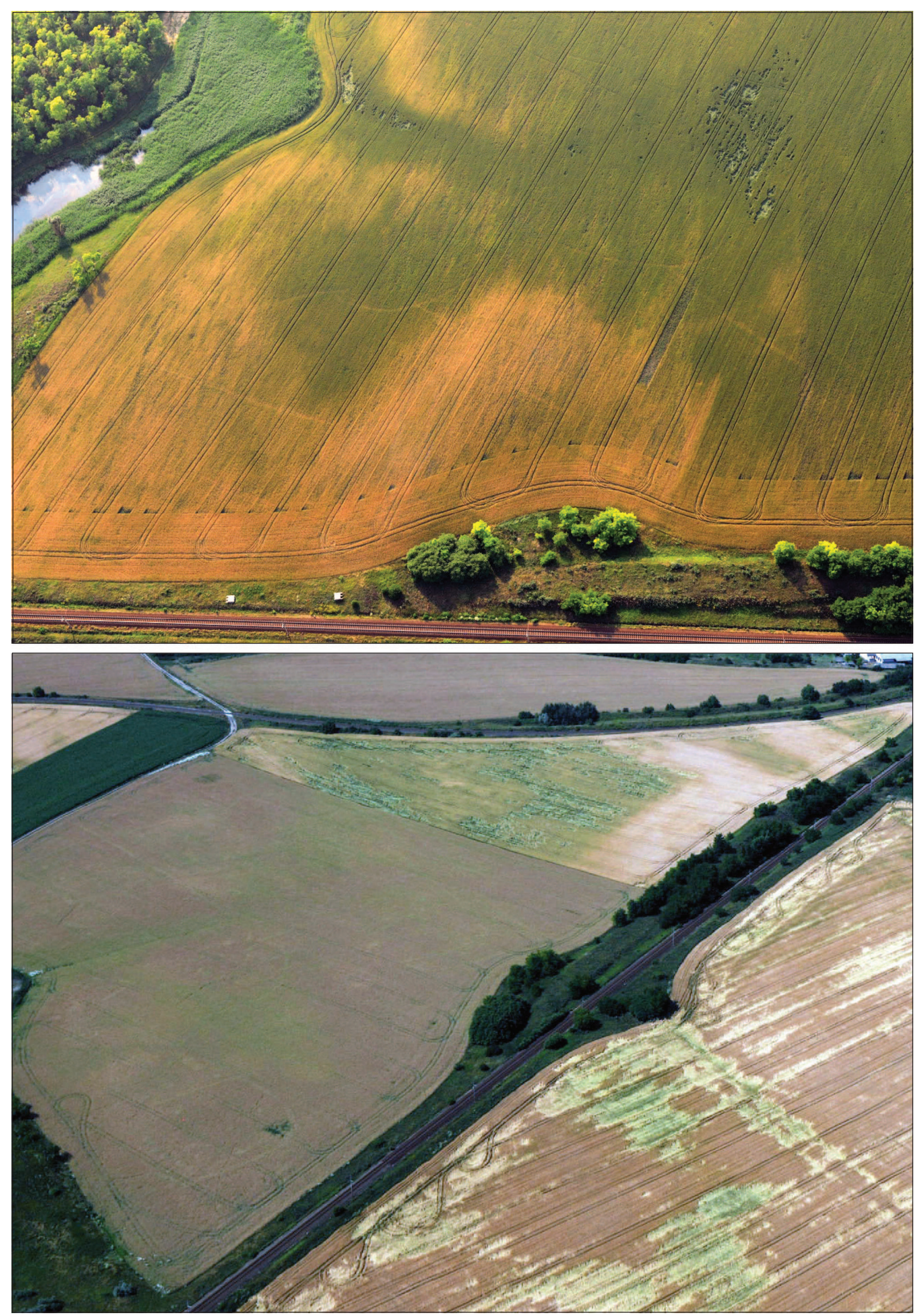

Fig. 3. The view of the eastern section of the site from 26th June 2015 (above), and a larger section of the site from southeast on 11th June 2011 (below) (photos: Z. Czajlik). 
destroyed during agricultural activity (Fig. 3). Due to the lack of enough images and accurate ground control points the georeferencing could only be made with low accuracy. Therefore, we did not make a detailed explanation of these phenomena, and their comparability with other sources such as magnetometer prospection and excavation is also limited. We also have images related to the opposite side of the Dohányos patak from the same date in 2011. This site can be characterized by features similar to those mentioned above.

We principally focused our attention on the documentation of the ongoing excavation in the summer of 2019. Zoltán Czajlik has carried out a flight on the 11th of June, and thus the first stage of the excavation has been documented. Another benefit of the survey was the detection of crop marks on the northern side of the current railway track. The sporadic traces of pits are visible in the growing rape, which suggests that the archaeological site is extending to this plot as well. The condition of the rape and grass grown next to the excavation did not allow us to get additional information in comparison with the earlier images about the structure of the site.

After the fieldwork, the excavated archaeological features were also surveyed stage-by-stage using a DJI Phantom 4 Pro quadcopter. The drone was manually piloted during the flights, kept in mind the necessary overlapping between the images. The flying altitude was varied between 11 and 16 meters. Besides the vertical exposures, oblique images were also taken if it was required in order to avoid blind spots during the 3D photogrammetry procession. The work resulted in a high-resolution orthophoto mosaic and a digital surface model (Fig. 4), which proved to be useful not only as a visualising tool but also as an aid for the documentation after the excavation. The surrounding plot has been documented as well. The flight of the
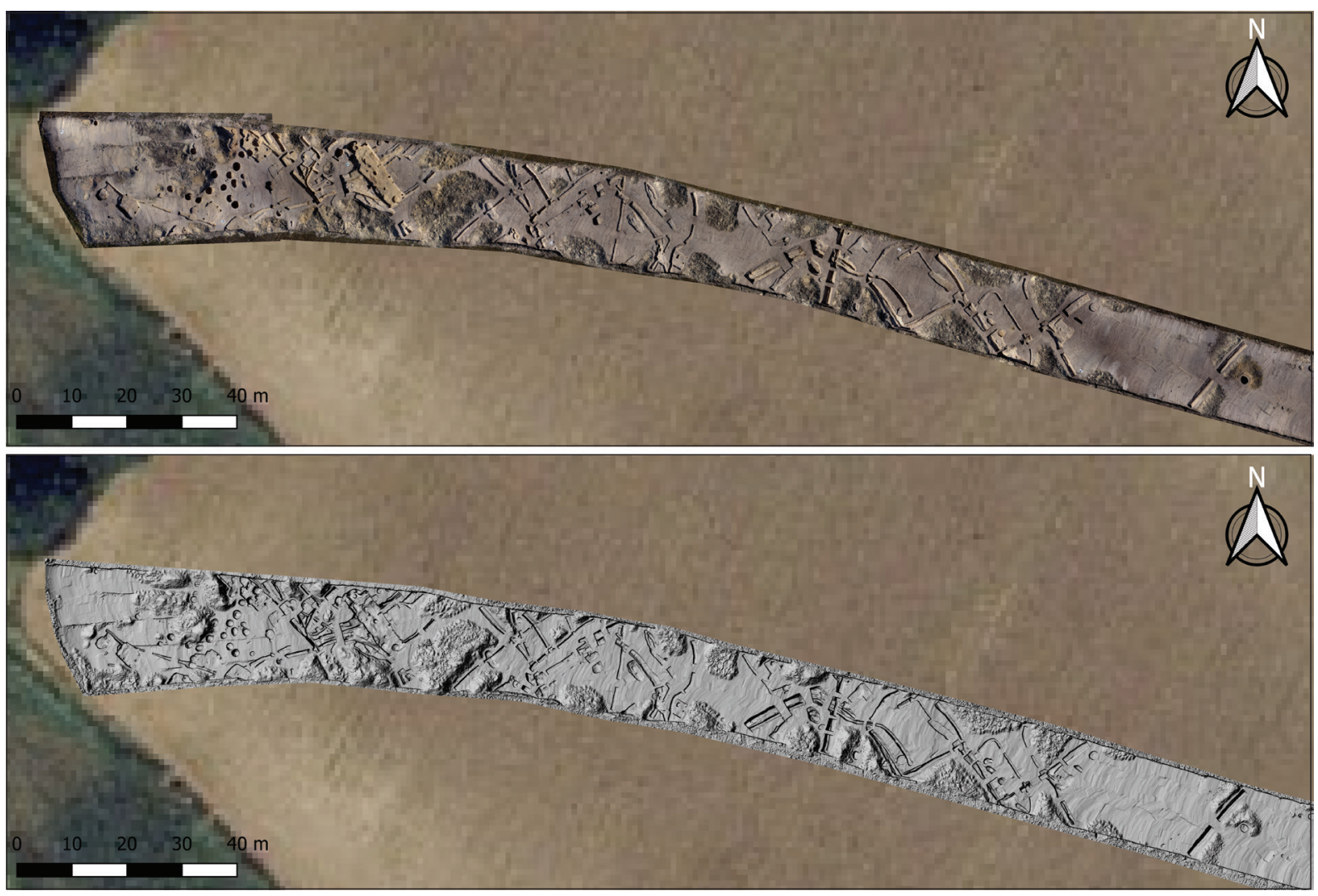

Fig. 4. The western section of the excavation: orthophoto mosaic (above) and shaded relief (below) (graphic: L. Rupnik). 
drone was automatically carried out in the altitude of 60 meters according to a path predefined in DJI Ground Station software. The DSM created on the basis of these images is showing the micro-morphology of the site well (Fig. 5). The crop marks of further archaeological objects appeared in the orthophoto especially in the north-western part of the site (Fig. 6).

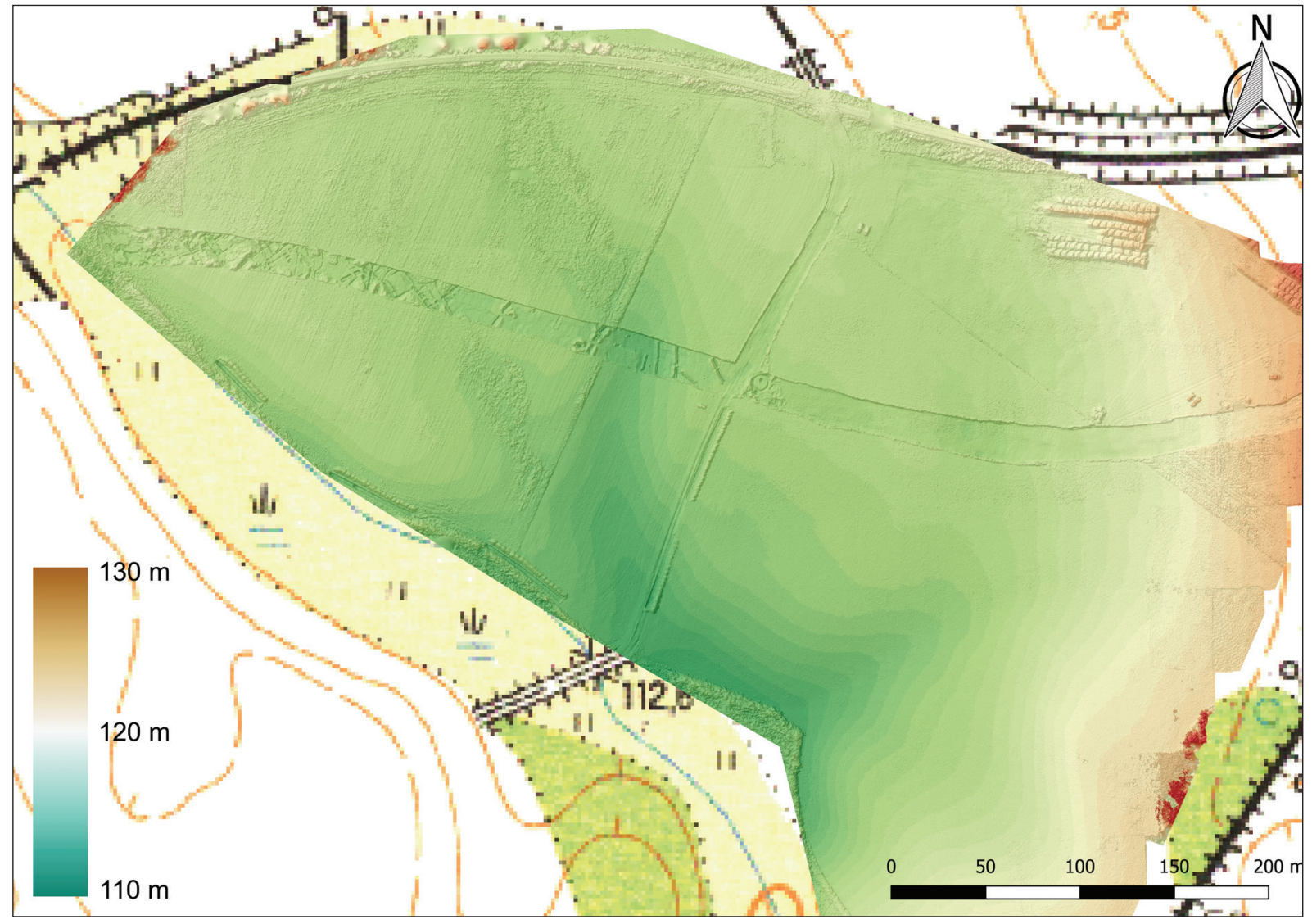

Fig. 5. The Digital Surface Modell (DSM) of the site (graphic: L. Rupnik).

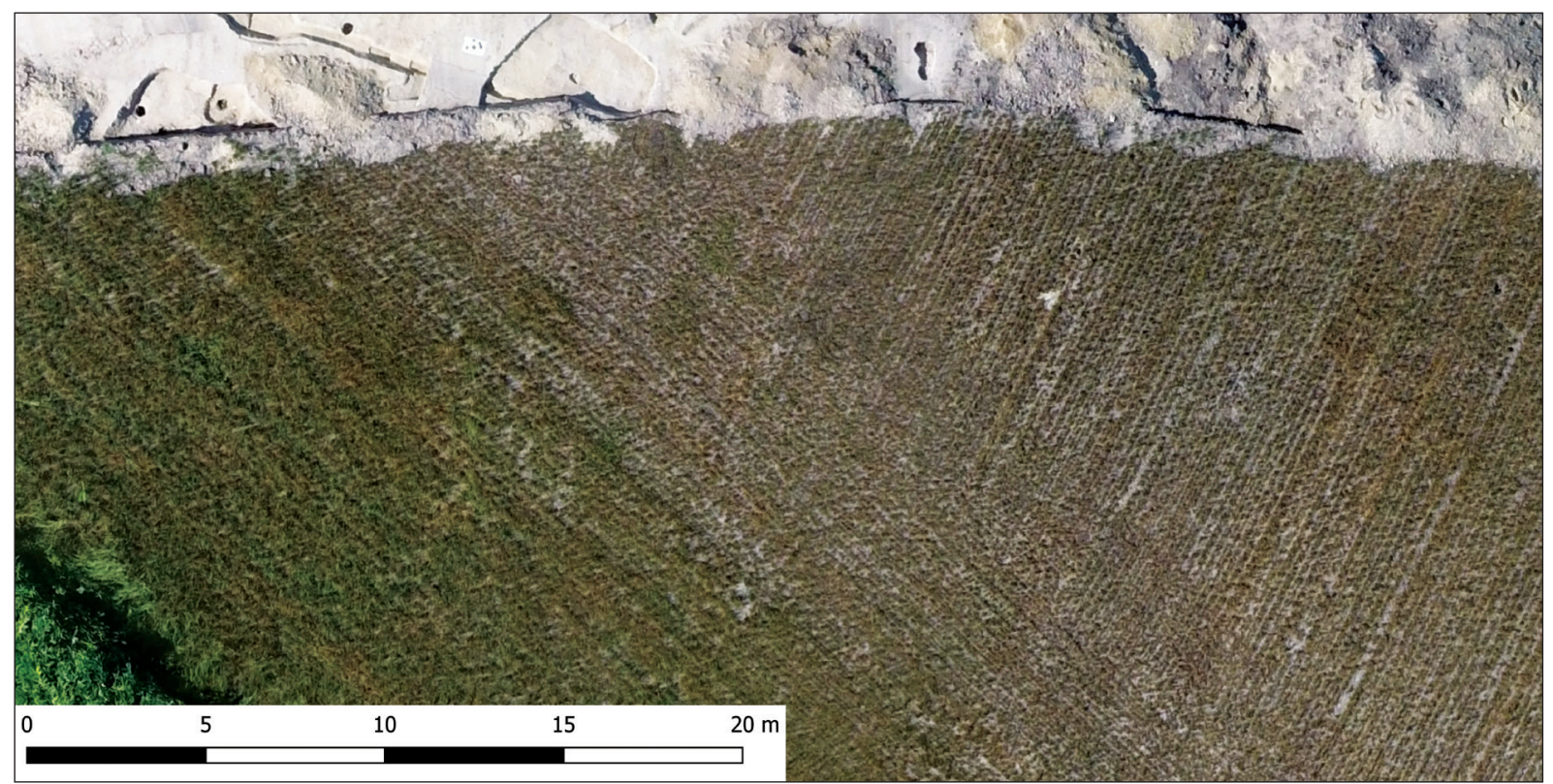

Fig. 6. Faint positive crop marks appear in the pasture close to the northern track by its western end (photo: L. Rupnik). 


\section{Geophysical measurements}

The magnetic prospection was conducted in two phases using a Sensys fluxgate gradiometer. In both occasions we used a manually operated SENSYS MAGNETO ${ }^{\circledR}$ MXPDA 5- channel system, with the gradiometers set at $0.5 \mathrm{~m}$ intervals. Data recording was performed with a GPS-supported GNSS system with real-time correction, therefore the sampling distance along the direction of measurement was $3-5 \mathrm{~cm}$. The raw data from the field measurements was processed in the Castle Headquarters Integrated Regional Development Centre by Mihály Pethe. During the processing, raw data was interpolated into a regular $0.25 \mathrm{~m} /$ pixel grid and was reduced to the pole and filtered. Altogether 8.09 ha was surveyed during the 2017 and 2018 field campaigns in this area (Fig. 7).

Modern age disturbances, mainly dipole features spread on the whole survey area mostly due to the agricultural cultivation. Higher disturbances can be observed on both ends of the northern track and the western end of the southern track.

The geophysical measurements identified an extensive ditch system almost on the whole survey area, and smaller uncovered areas can be located on the eastern part of the northern track. Based on the spatial layout, the direction, superposition and anomaly type, the ditch system most likely belonged to multiple periods. The rectangular and angular ditches are frequently aligned into NE-SW or perpendicular direction. Most of these features are located on the northern track and the western part of the southern track. On the wider southern bound numerous "U"-shaped ditches are observable on the western side. Oval or curved ditches are more frequent on the northern track, but a large, probably settlement-enclosing ditch overlapping the "U"-shaped ditches is visible on the mid-section of the southern track. Based on aerial photographs, certain NW-SE-directed ditch sections on the eastern side can be connected to the mid-20th century dirt road network (Fig. 7).

Further anomalies referring to archaeological features are mostly located on both sides of the Dohányos-völgyi-árok watercourse. The most intensive settlement remains are observable in the mid-section of the southern track inside the enclosure ditch. Large ( 5 by 4 meters), moderately magnetized houses also appear inside the enclosure ditch. Further measurement areas sporadically contain additional settlement feature anomalies, although these anomalies are always in connection with the ditch system (Fig. 7).

Another magnetic survey has been conducted using GSM19W Overhauser magnetometers by the Institute of Archaeological Sciences of Eötvös Loránd University in the western part of the plot between the track and the Dohányos Stream. The survey area was chosen based on the object density of the excavation and the crop marks that were visible even from the ground view in the pasture. The size of the measured area was approx. 0.44 hectare and it connected to the section, which was measured with the Sensys fluxgate gradiometer. The measurement was proceeded in variometer layout with the sondages set at a $75 \mathrm{~cm}$ interval. The temporal change of the Earth magnetic field was recorded by local base measurement. Data acquisition was supported by Trimble Geo 7 GPS with the later correction of the location according to the base stations performed by Balázs Holl. The raw measurement data has been processed by Sándor Puszta. The higher density of disturbance in the track mainly caused by dipole features can also be observed by this measurement. The connecting sections of the extensive trench system and enclosures can be identified as well. Although the main characteristics are similar, 

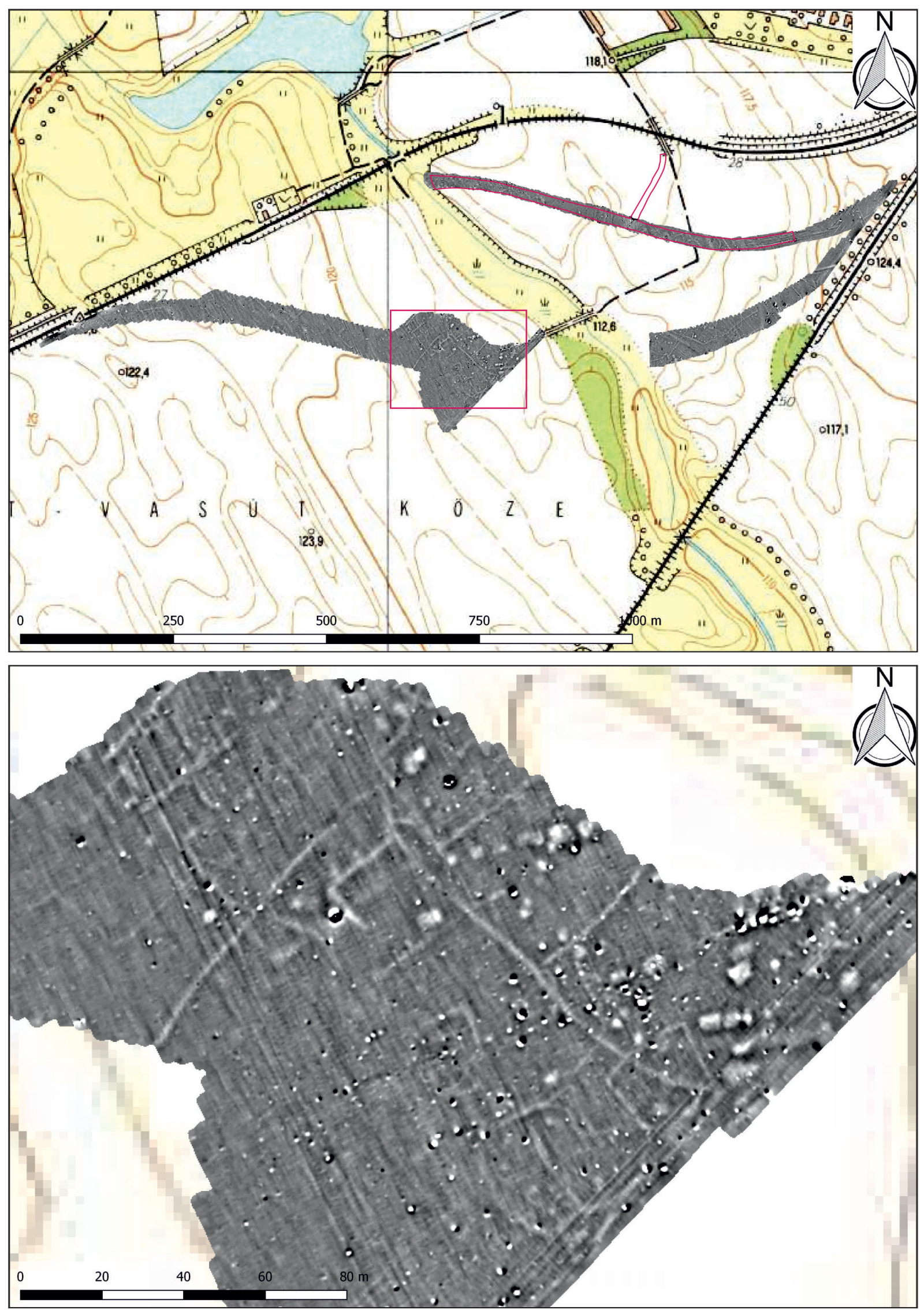

Fig. 7. Overall map of the magnetic prospection carried out in the two desired tracks using Sensys fluxgate gradiometer and the rural settlement on the southern shore of the Dohányos Stream according to the magnetic prospection (graphic: G. Mesterházy). 
the anomaly map of the GSM19W Overhauser magnetometer appears to be more detailed than the Sensys fluxgate gradiometer. However, it should be noted that the major structures can be observed better in the areas surveyed by the latter method (Fig. 8). The two different prospecting methods have essentially provided similar anomaly maps that complement each other as far as it can be assessed based on the relatively small connecting areas.

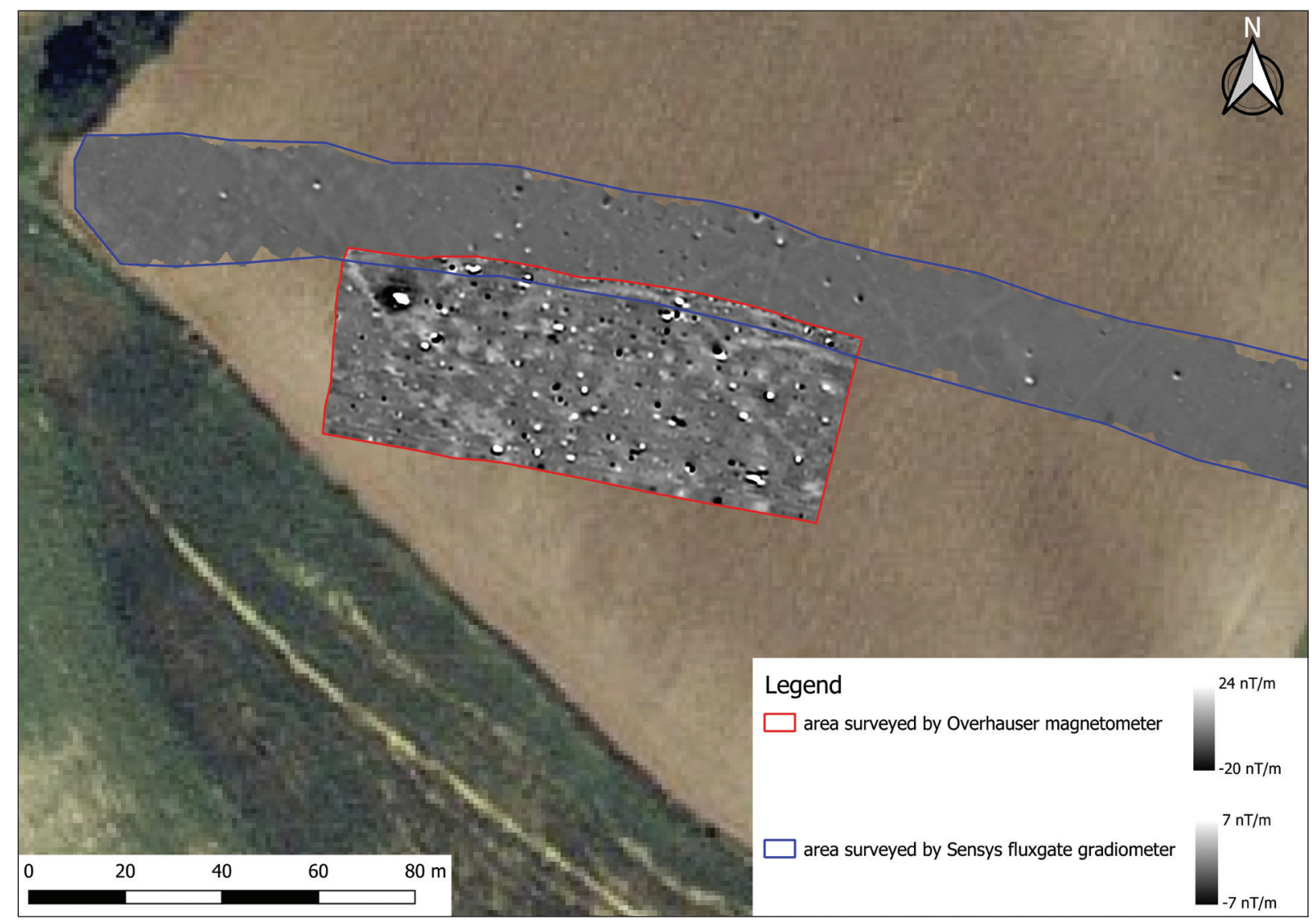

Fig. 8. Combined results of the magnetic surveys applying two different methods (graphic: G. Mesterházy - L. Rupnik).

\section{Field survey}

The field survey was completed on the 20th of March 2017. The area was examined between two designated tracks, considering that the investigated field has two types of surface. The eastern side of the field was covered with a harrowed field, and the western side was cultivated (Fig. 9).

During the process of the field walking, we marked the line with the new track, and we kept a distance of 20 meters from each other. We used handheld GPSMAP 62s by Garmin and we marked every single fragment of ceramic finds.

Two sites have been identified in the area designated for research: a new one, Pusztaszabolcs-Kullancsos, and the well-known Dohányos völgy északi part (82537). After the geophysical research the two sites were contracted and became parts of the site of Dohányos völgy északi part (82537).

Pottery shards were found in two distinct groups on both sides of the research area. One group of the pottery shards was located on the western part of the site, and the other one on the eastern side. 


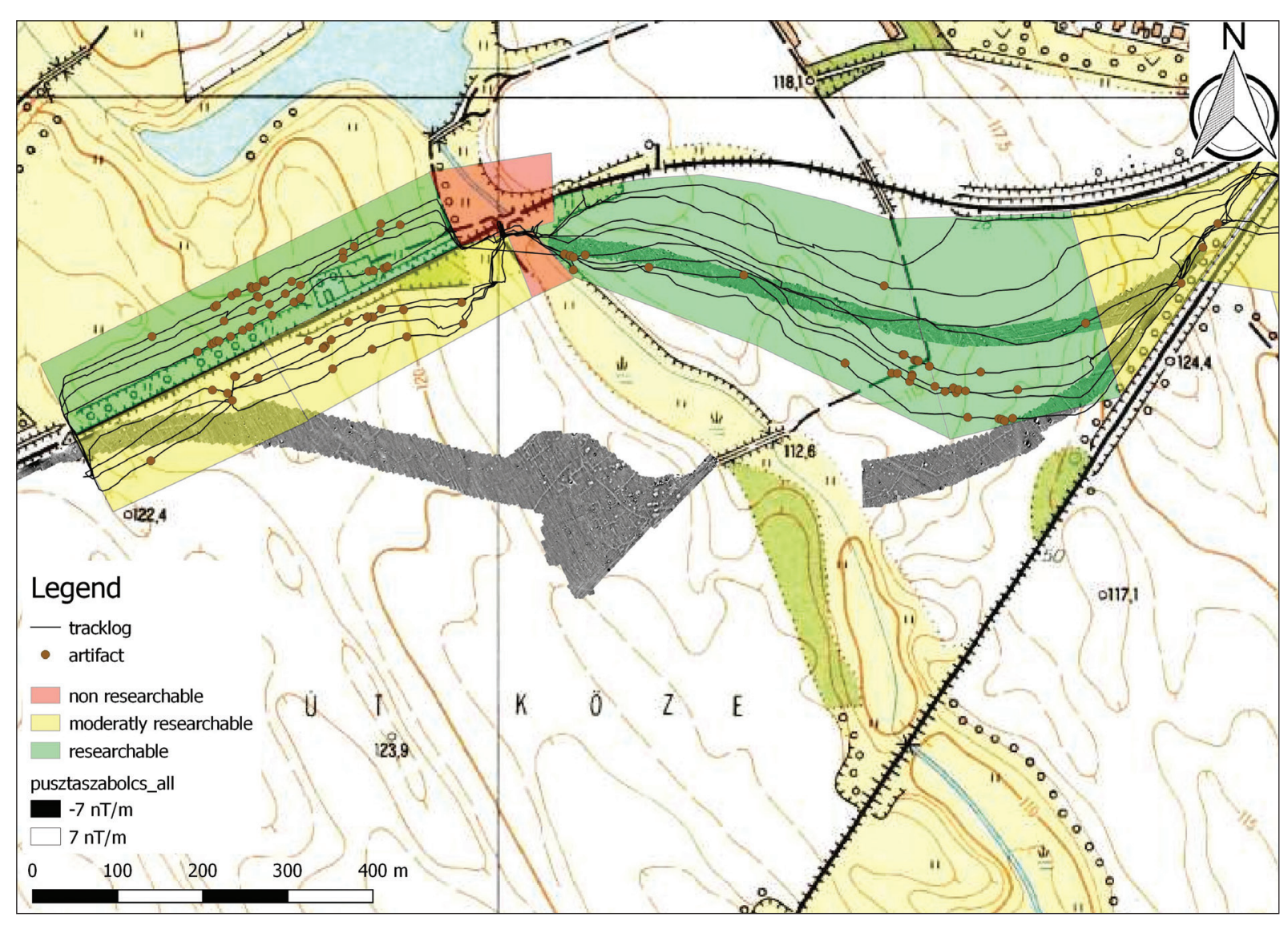

Fig. 9. The extension and results of the field survey carried out in 2017 (graphic: G. Mesterházy).

We have found 9 Prehistoric, Roman Age and Árpádian Age pottery shards on the western side of the field survey. Their measured dimensions (height-width) were between $1.1 \times 9 \mathrm{~cm}$ and $2.5 \times 3 \mathrm{~cm}$.

We have found 29 pottery shards from the times of the Árpádian Age and the Middle Ages on the eastern side of the site. Their measured dimensions (height-width) were between $0.8 \times 1.5$ $\mathrm{cm}$ and $2.8 \times 3.8 \mathrm{~cm}$. In the western part of the researched area the pottery shards were found in a well-localized section of 30 meters in diameter, while the shards on the eastern side of the site were scattered.

\section{Metal detector survey}

We searched for finds with an XP Deus (with HF coil head) metal detector in two stages at the excavated area. First, we tested the area on the original surface and then re-examined the area during the multi-layered removal of the humus. Most of the scattered metal objects were found on the heavily populated stretch of the stream and on the loess plateau of the eastern section. Beside the undatable iron and bronze fragments, the Late Bronze Age tools, Roman and Árpádian Age coins represent a group of objects of informational value. Fragments of a Bronze Age weapon set were scattered over a well-defined area. The scattering of the Roman coins and some fibula fragments clearly correlates with the location of the buildings. On the sections with only trenches and without buildings, the lack of metal finds can be clearly demonstrated (Fig. 10). 


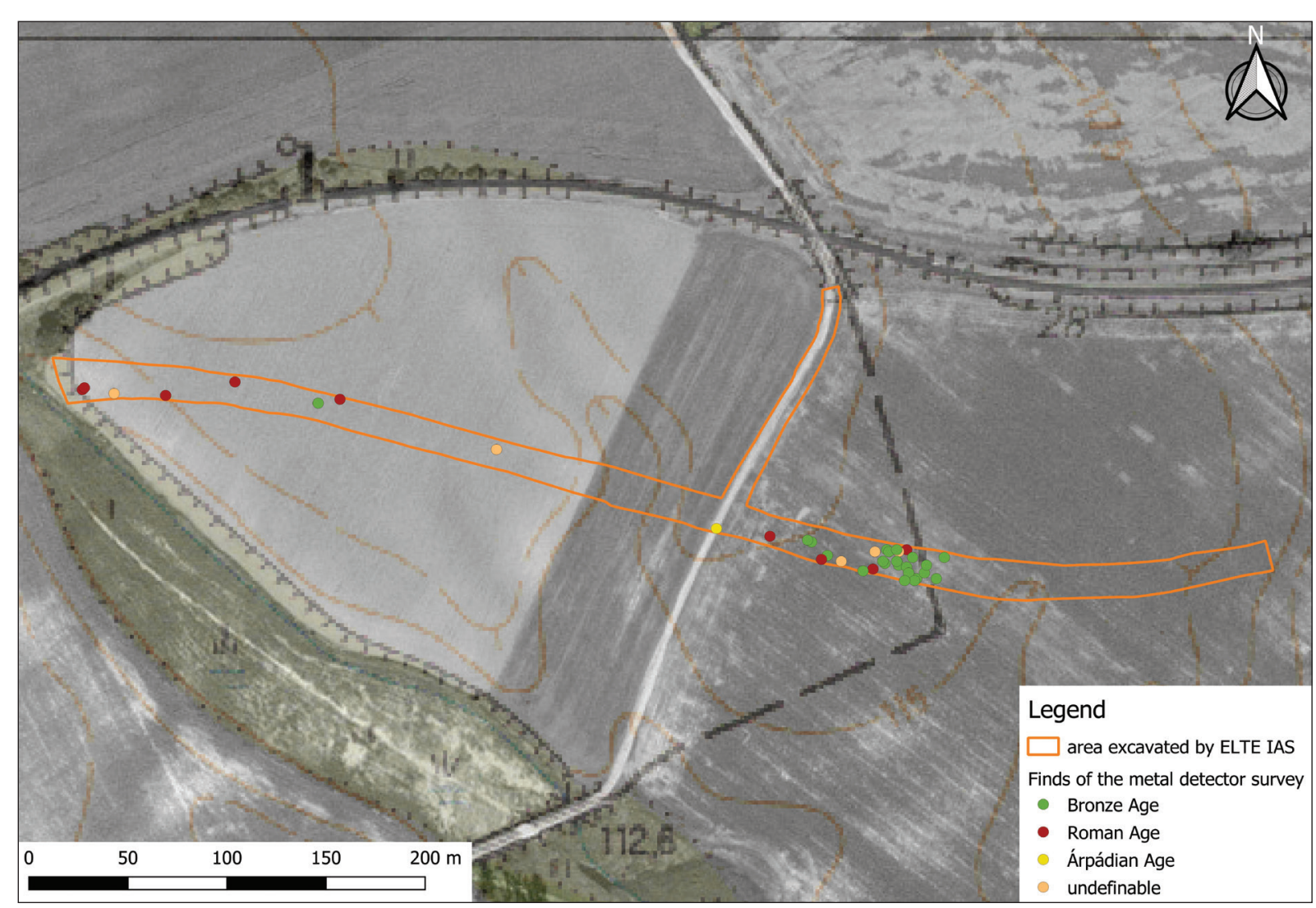

Fig. 10. The excavated area and the artefacts that came to light in the course of the complementary metal detector survey (graphic: L. Rupnik).

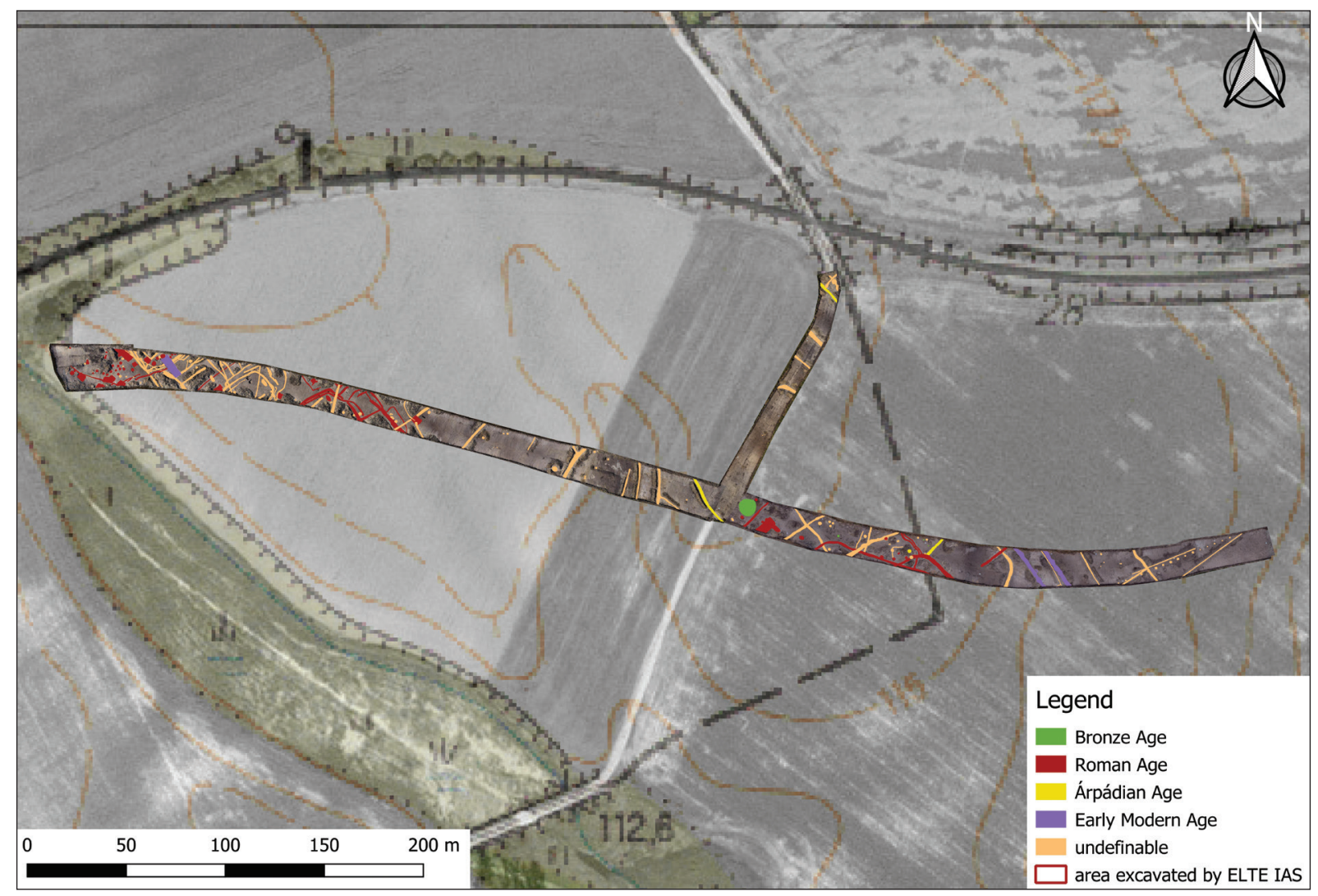

Fig. 11. Overall map of the area excavated by ELTE-IAS with the datable archaeological features (graphic: L. Rupnik - G. Váczi). 


\section{Results of the excavation}

The area was first used during the Late Bronze Age (Fig. 11). Among the excavated objects on the eastern section, there were three small, shallow pits and a circular trench that may be datable to the 1300s BC. A shallow pit, slightly larger than a posthole is worth mentioning among the pits, as it contained an intact mug. We did not find any traces of digging within the trench that was 9 meter in diameter. A pottery set (a jug, a strainer, a lid, bowls and cups) deposited in the trench dated the circular trench into the late Tumulus - early Urnfield period. At the highest point of the area enclosed by the circular trench and pits, we have found some blade fragments of a Bronze Age sword and dagger already in the cultivated soil layer. Thanks to the layered humus removal and the continuous use of the metal detector, we found the fragments of a sword, an axe, a spearheads, a dagger and a razor (Fig. 12), scattered by the ploughing in an approximately 10-meter circle. We cannot connect the assemblage to any of the pits, as all the finds came to light in the layer of the upper $40 \mathrm{~cm}$. Besides the weapon set, we have also found several fragments of bronze pendants and pins in Roman Age features situated in the area between the circular trench and the pits. We may presume that they were pieces of another (jewellery) set.

The excavation data confirmed the Roman part of the site identified in the course of the field survey. Based on the stray coins and the large number of ceramic artefacts, the settlement was inhabited in the 3th-4th century AD (Fig. 13).
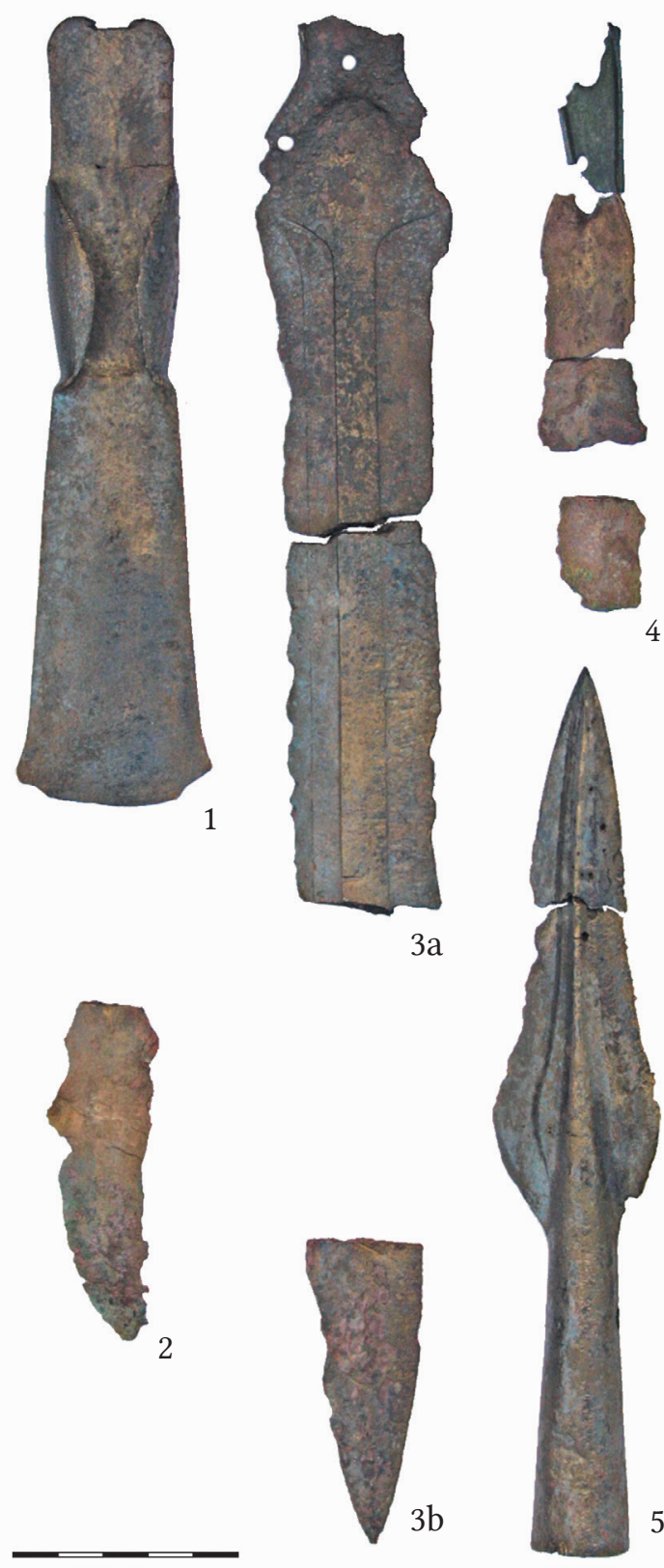

$3 a$
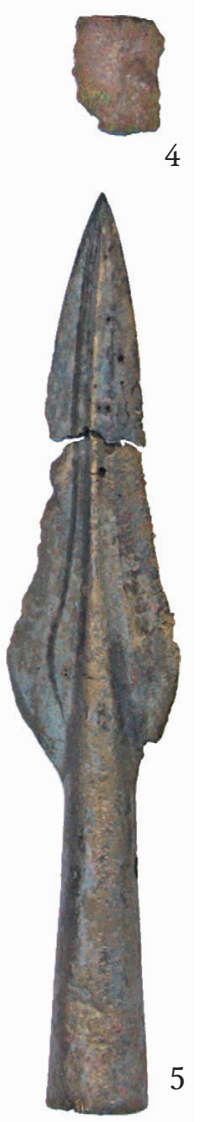

Fig. 12. 1-5 - Selection of the Late Bronze Age artefacts found during the metal detector survey (photo: G. Váczi).

The most densely populated part of the settlement is situated on an approx. 100-meter wide area with sandy subsoil along the creek. We unearthed the majority of the semi-subterranean buildings with a $4 \times 5$ meter floor area and the storage pits here. This area includes a thin, grid-structured trench system, to which some isolated buildings and pits connected (Fig. 11).

On one of the loess plateaus of the eastern area of the site, the Roman ditch system included a large semi-subterranean building of $5 \times 10$-meter floor area (Fig. 14). We found remains of plastered floor in spots at the bottom of the building. Three rows of columns supported the roof structure, the rows aligned with the longitudinal axis of the building, its entrance opening southeast. There were two furnaces on the northwest side of the building. One is a freestanding, tegula-based, rectangular structure, while the other is a round, clay-based 

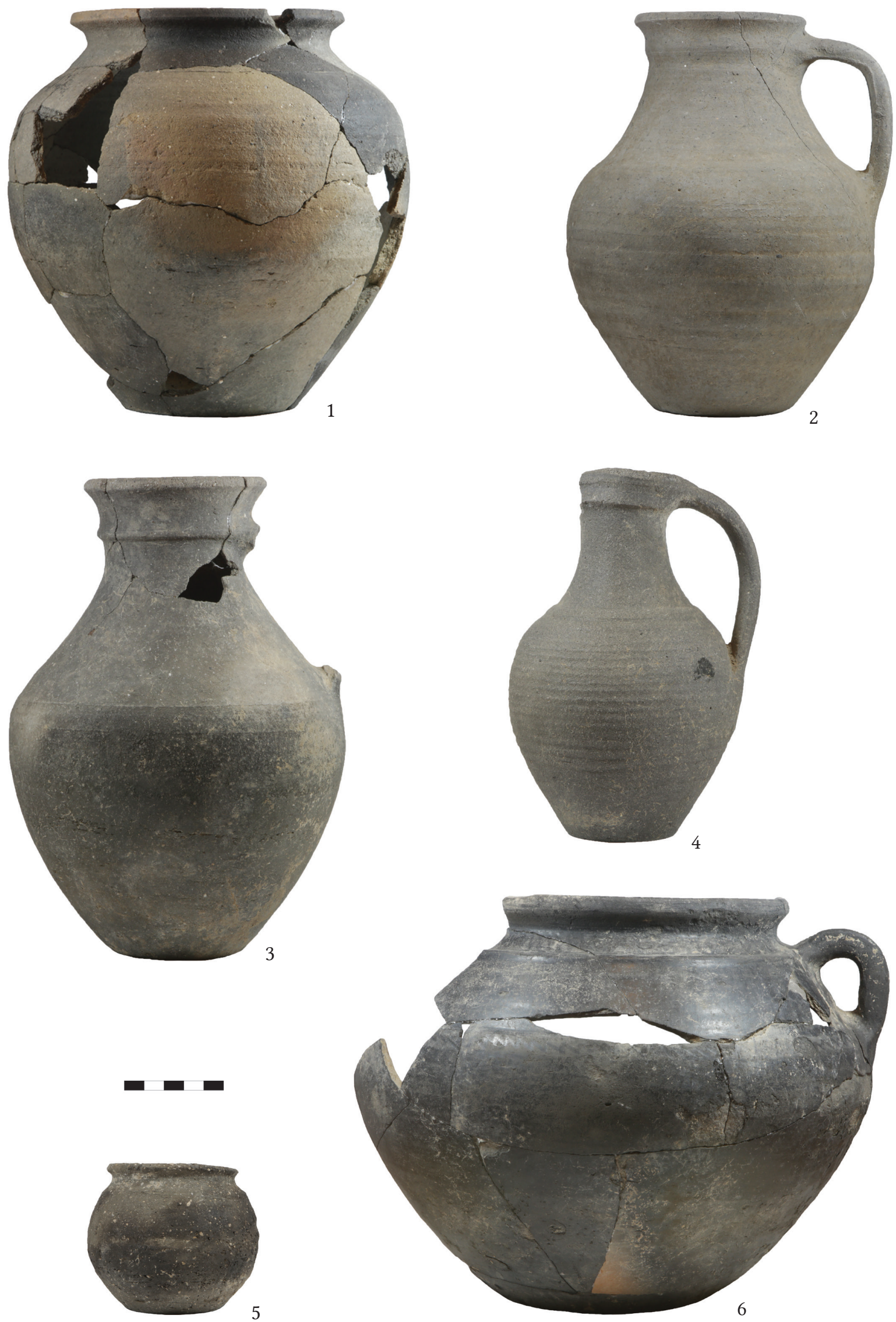

Fig. 13. Selection of the pottery found in the Roman Age features (photos: K. Fülöp). 
oven carved into the side of the building. A large amount of iron objects, mainly fragments of knives, came to light in the building. We found whole animal skeletons placed in pairs into the bottom of the 2.5-3-meter deep, round pits situated by the north-western side of the building.

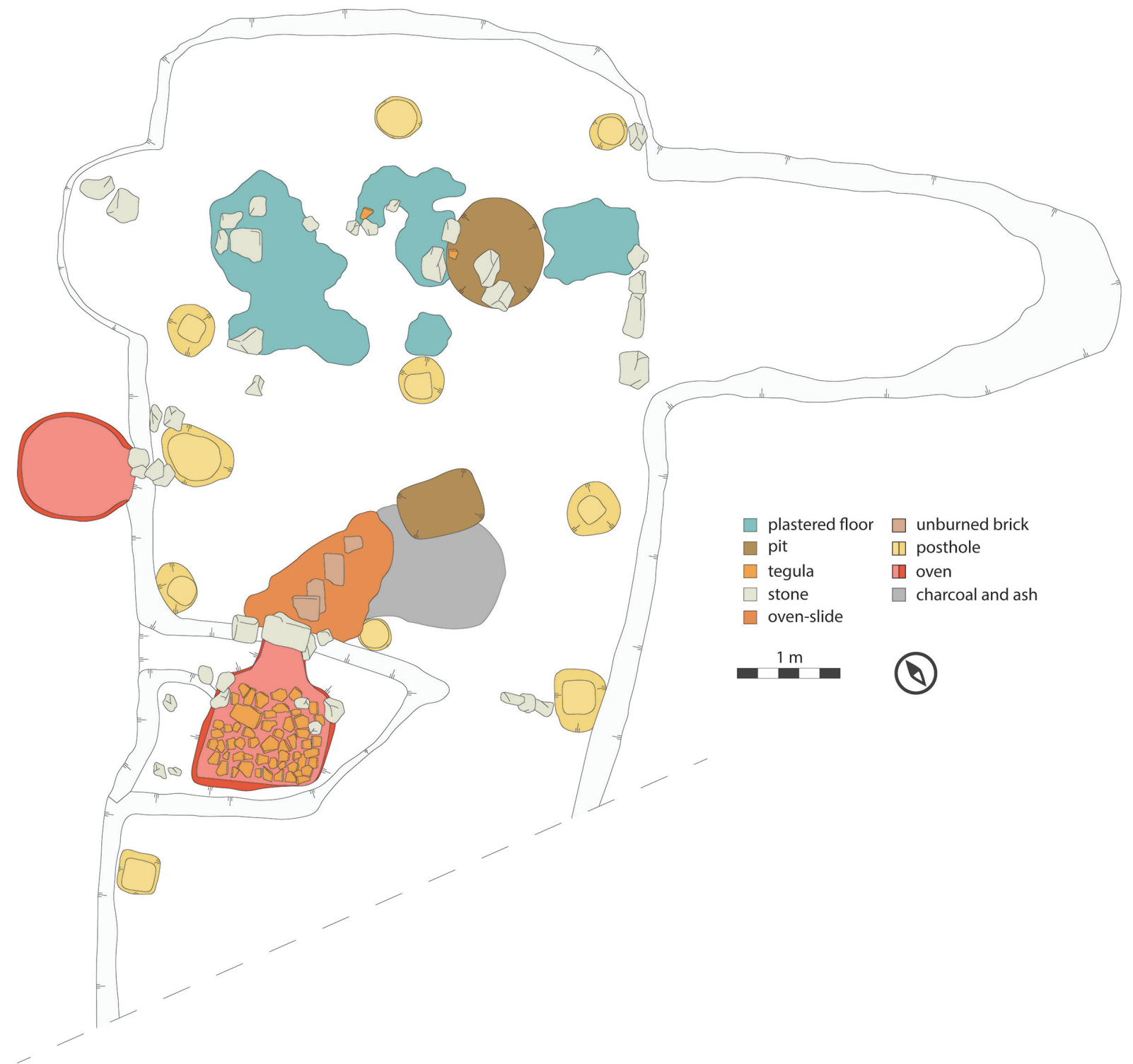

Fig. 14. The survey map of the semi-subterranean building No. 18.18 (graphic: K. Fülöp).

The number of the Árpádian Age artefacts is not significant at the site, only some segments of a ditch system and a few pits could be classified into this period (Fig. 11). The above-mentioned features can be considered as the eastern periphery of the Árpádian Age settlement discovered at the site of Pusztaszabolcs-Sínek (93147). A large, semi- subterranean building of $12 \times 4$-meter floor area, dating from the Late Medieval Period was excavated in the intensely populated section of the site. The row of columns running along the longitudinal axis of the building was complemented by rows of smaller columns deepened into the longitudinal walls of the building on the two sides. Its material consists mainly of iron objects, among which a silver-plated, wide sole stirrup is notable. 


\section{Methodological observations}

Although we aimed to describe the preliminary results of the research taken place in the archaeological site, some important methodological observations can be also highlighted here. The most fundamental one is the comprehensive use of non-invasive archaeological methods from the aerial imagery to the geophysical prospection not only before the excavation but also during it, in order to exploit all possible information about the site. The procession of the collected data in GIS environment is also essential that enables to compare and match them (Fig. 8). We are facing several questions during this procedure.

How accurate is the impoundment of the archaeological site according to the dispersion of the surface finds? As we have seen, the aerial archaeology and the geophysical prospection proved to be more effective from this point of view. However, neither the date nor the multi-periodicity of the site could be given comfortingly without these finds.

The interpretation of the magnetic anomaly map and the aerial imagery equally has a certain level of suspense. Both methods have their limits, because the conditions like the type and moisture level of the soil, the vegetation, the scale of the erosion etc. all can affect the efficiency of these methods in either positive or negative way. How can we monitor the erosion of the area in the photographs taken between 1968 and 2019, and how does it affect the possible interpretations? Which anomaly or crop mark has archaeological origins? And which can be seen as disturbance or modern feature? According to the results of the excavations, the interpretations can be refined, and the experiences can be turned to our favour in the upcoming researches. Despite the intensive application of the aerial archaeology, the coherent map of the site could not be produced, which was caused partly by the unfavourable circumstances, and partly because traditional aerial photography did not produce properly rectified images. (It should be noted that the primary goal is always to document the archaeological sites, and taking additional photos needed for rectifying may require a significant amount of extra time and cost during the flights.) The magnetometer prospection proved to be more effective in the Dohányos völgy. However, the map that was prepared based on aerial images has provided additional data to the magnetic anomaly map, since the geophysical measurements were only conducted in the designed tracks of the future railway.

Finally, we have to draw attention again to the importance of 3D photogrammetry in the documentation of the excavation and its surroundings. We strongly believe that this methodology is radically changing the routine of the daily work. It is necessary to prepare new tutorials about how this method should be adopted to the existing archaeological practices. 
